\title{
Estratificación del riesgo de transmisión malárica en la región Caribe colombiana.
}

\section{Malaria risk stratification in Colombian Caribbean}

\author{
Julio Cesar Padilla $\mathrm{R}^{1}{ }^{\mathbb{D}}$, Luis Mariano Acuña $\mathrm{C}^{2}{ }^{\mathbb{D}}$, Mario Javier Olivera $\mathrm{R}^{3}$ (D)
}

\begin{abstract}
RESUMEN
Objetivo: Determinar el riesgo de transmisión malárica en la región Caribe colombiana. Materiales y métodos: Estudio observacional de tipo descriptivo y retrospectivo en 167 municipios de la región entre los años 2010-2019. Se clasificaron los municipios como: E4: aquellos con casos autóctonos de focos activos y residuales; E3: receptivos, sin casos autóctonos, y con riesgo de importación del parásito; E2: receptivos sin transmisión y baja vulnerabilidad; E1: no receptivos ubicados por encima de los 1.600 msnm donde no existe riesgo comprobado de transmisión; acorde a la metodología de estratificación de la OPS (2019) Resultados: El $5 \%$ (8) de los municipios se clasificaron como E4, siete en el departamento de Bolívar y uno en La Guajira. El 72,4\% (121) de los municipios se clasificaron E3 y el 22,8\% (38) como E2. La carga acumulada de casos en la región fue de 23.285 casos, con predominio de Plasmodium vivax, y el 80,8\% (18.804 casos) de la carga se registró en los municipios E4. Conclusiones: La región Caribe colombiana evidencia
\end{abstract}

transmisión endemo-epidémica, focal y dispersa, variable y de muy baja intensidad. Existen dos focos de transmisión autóctona activa en el sur de Bolívar y el área rural de Riohacha, La Guajira.

Palabras claves: Estratificación, Riesgo, Malaria, Región Caribe, Transmisión.

\begin{abstract}
Objective: Determine the malaria risk transmission in Colombian Caribbean. Methods: A descriptive and retrospective observational study was conducted in 167 municipalities CoIombian Caribbean between 2010-2019. The municipalities were classified as: S4: Municipalities with native cases of active and residual foci; S3: Receptive, without native cases, and with risk importation of parasite; S2: Receptive without transmission and low vulnerability; S1: Non-receptive located above 1.600 meters above sea level in which there is no proven risk transmission, according to criteria proposed by
\end{abstract}

Citación (Vancouver): Estratificación del riesgo de transmisión malárica en la región Caribe colombiana. Rev Avances en Salud; 2021. (5)1 :22-23 . doi: $\underline{10.21897 / 25394622.2538}$

\footnotetext{
'Medico Esp., Consultor Independiente, Staff \& Health SAS - Bogotá, Colombia Correspondencia: jcpadilla59@yahoo.es

${ }^{2}$ Biólogo, Grupo de Entomología, Dirección de Investigación en Salud Pública - Instituto Nacional de Salud de Colombia INS. Iacuna@ ins.gov.co

${ }^{3}$ Medico M.Sc., Grupo de Parasitología, Dirección de Investigación en Salud Pública - Instituto Nacional de Salud de Colombia INS Bogotá, Colombia. molivera@ins.gov.co
} 
PAHO. Results: The municipalities classified as S4 were $5 \%$ (8): seven in Bolívar and one in La Guajira department. The municipalities classified as S3 were 72,4\% (121) and S4 were $22,8 \%$ (38). The accumulated burden of cases in the region was 23.285 cases, with a predominance of Plasmodium vivax, and $80,8 \%$ (18.804 cases) of the burden was registered in municipalities S4. Conclusions: The Colombian Caribbean evidence endemic-epidemic transmission, focal and dispersed, variable and of very low intensity. There are two active foci of indigenous transmission in southern Bolivar and rural areas of Riohacha, La Guajira.

Key words: Stratification, Risk, Malaria, Caribbean Region, Transmission

\section{REFERENCIAS}

1. Padilla-Rodríguez JC, Olivera MJ, Ahumada-Franco ML,Paredes-Medina AE. (2021). Malaria risk stratification in Colombia 2010 to 2019. Plos one 16(3): e0247811.https://doi. org/10.1371/journal.pone.0247811

2. Instituto Nacional de Salud. Informe evento malaria. Bogotá, Colombia: $2019 . \quad$ https://www.ins.gov.co/ buscadoreventos/Informesdeevento/ MALARIASEMESTREI2019.pdf.

3. Organización Panamericana de la Salud. Manual de estratificación según el riesgo de malaria y eliminacion de focos de transmisión: región de las Américas (Draft). Washington DC; 2019. https://www.paho.org/hq/ index.php?optioncom docman\&view =download\&slug=malaria-technicaladvisory-group-session-8-2019-onlyin-spanish\&Itemid=270\&lang=en. 